[Vicino Oriente XXIII (2019), pp. 65-80]

\title{
KUB 37.122: A MESOPOTAMIAN LEXICAL LIST?*
}

\author{
Federico Giusfredi - Valerio Pisaniello \\ University of Verona
}

\begin{abstract}
In this paper, we will offer an edition and commentary of the fragment KUB 37.122, usually referred to as a Samenliste, but generally not included among the lexical lists from the Hattusa archives. We will also discuss some peculiarities of the contents, the syllabary, and the graphemics of the text, and we will try to contextualize the text within the complex scenario of the Akkadian texts written, or copied, in the Hittite capital city.
\end{abstract}

Keywords: Akkadian; Sumerian; lexical lists; medical texts; plant names

\section{LEXICAL LISTS AND THE PERIPHERY OF THE CUNEIFORM KOINÈ}

Lexical lists represent a peculiar genre in what - using the label in a very general fashion - we could call the Ancient Near Eastern literature. These texts usually contain a list of lexical entries that are presented in parallel columns, in one or more languages of the Ancient Near East. ${ }^{1}$ The languages that are usually represented in Mesopotamia are Sumerian and Akkadian, while other languages (Eblaite, West Semitic, Hittite, and Hurrian) may appear in documents recovered from local archives.

In the archives from Hattusa, the main capital city of the Hittite Empire, a number of lexical lists have been recovered, most of which are in fact copies or local elaborations of traditional lists that belong to the Mesopotamian tradition. These documents were recorded by Emmanuel Laroche under the CTH numbers from 299 to 309, and the following Mesopotamian lists are represented in the sub-corpus: $\mathrm{S}^{\mathrm{a}}, \mathrm{S}^{\mathrm{o}}$, Diri, Erimhuš, $\mathrm{Ur}_{5}$-ra, Ura, Izi, Kagal, Sag, $\mathrm{Lu}_{2}, \mathrm{Ea}$, and possible fragments of an An list. ${ }^{2}$

The functions of lexical lists were certainly manifold, and included transmission of scribal knowledge - as is evident from compositions that are ordered by graphemic criteria and the transmission of the scholarly conception of the world - as indicated by compositions that are organized based on semantic fields and semantic associations. Possibly, they were also a vehicle for the teaching and learning of foreign languages which, in a civilization in which script and language formed an inseparable unit, cannot be discussed as a process separated from scribal education.

\footnotetext{
This paper is a product of the project PALaC, that has received funding from the European Research Council (ERC) under the European Union's Horizon 2020 research and innovation programme (Grant Agreement $n^{\circ}$ 757299). Abbreviations follow the conventions of the Reallexikon der Assyriologie und Vorderasiatischen Archäologie. We wish to thank Mark Geller and Strahil Panayotov for providing us with valuable insight regarding some of the names of the plants attested in the list; however, the responsibility for the contents of this paper and for any shortcomings belong to the authors: Federico Giusfredi authored sections 1, 2, 3, and 5; Valerio Pisaniello authored section 4. Both authors wrote section 6.

$1 \quad$ RlA 6, 609-641, for an overview.

2 For the publications, MSL 3, MSL 12-13, MSL 17. Most of the lists found in the Hittite archives are discussed in the dissertation by Scheucher (2012).
}

ISSN 0393-0300

e-ISSN 2532-5159

Rivista Open Access 


\section{THE ATYPICAL LISTS}

Among the lists found in Hattusa, there are also cases of "atypical" lists that cannot be ascribed to a known original in the Mesopotamian collections. A number of them were discussed by Tobias S. Scheucher in his doctoral dissertation, ${ }^{3}$ and they are, in principle, the fragments recorded by E. Laroche under CTH number 309 and the better-preserved vocabulary KUB 3.94, with duplicate KBo 26.50 (which, in MSL XIV, 108 was tentatively compared with the Mesopotamian series $S^{a}$ and $S^{b}$ ). To what extent the atypical lists belong to a local re-elaboration of Mesopotamian tradition is difficult to tell, especially because most of the fragments listed in CTH 309 are difficult to analyse because of the poor state of preservation. However, the inclusion of the Hittite language, e.g. in the Hattusa version of Erimhuš KBo $1.44+,{ }^{4}$ easily shows that scribal re-elaborations took place in the local scribal circles of Anatolia.

The possibility of recognizing a lexical list strongly relies on the state of preservation of the epigraphic document. The presence of linguistically consistent content in parallel documents is the best indicator of the lexical nature of a tablet, while in some cases, even if the text is too fragmentary to recognize the structural correspondence, the organization of single columns may be helpful. The tablet we will discuss in the present paper, KUB 37.122 , only contains a single column on the obverse and the first signs of the second column, while the reverse, judging from the preserved portion, is uninscribed. So far, it has not been labelled as a proper lexical list, nor was it included by T.S. Scheucher in the corpus he analysed in his doctoral dissertation.

E. Laroche, in his catalogue, reserved a whole CTH number to this atypical fragment: CTH 815, liste de semences. The tablet does indeed contain what looks like a list of names of seeds. Lines 2' to 11' and then 14' are readable on column i, while column ii only shows the initial NUMUN $\operatorname{sign}^{5}$ - or part thereof - for lines 3' to 15 '.

The resistance against classifying KUB 37.122 as a lexical list may depend on several factors. First of all, the absence of any phonographic remains of column ii prevents us from knowing whether the second column of the text was written in a strongly sumerographic Akkadian, like column i, or if a second language was represented - which in all likelihood would have been Hittite. Second, there are to our knowledge no other known cases of lexical lists entirely dedicated to seeds. However, a caveat is in order here: the characterization of the whole composition as a liste de semences by E. Laroche was certainly not very cautious. Other fragments of the same tablet may emerge in the future, and it cannot be excluded that the lines preserved on KUB 37.122 might be merely a section of a larger list that did not contain only seeds. This does not obliterate the fact that no Mesopotamian list containing this long list of seeds is currently attested either, which puts our text in a position similar to the Hattusa "isolated vocabulary" KUB 3.94 (CTH 306).

In our opinion there is no reason to doubt that KUB 37.122 fully qualifies as a lexical text. Firstly, the lines of the two columns seem to be vertically aligned with each other,

Scheucher 2012.

MSL XVII, 98-116; Scheucher 2012, 610-646.

Labat no. 117; HZL no. 12. 
which make a correspondence between the entries very likely to have existed when the tablet was complete. ${ }^{6}$ Second, each line of column i contains a single entry, which is the name of a seed: there are no sentences; there are no predications; and there are no indications of a textual context, nor are there any numerals that would hint to a practical or administrative kind of list. Finally, the graphemic organization, with the sign NUMUN opening each line, is highly reminiscent of those lists that organize the contents based on the initial determinative/logogram.

\section{PECULIARITIES OF KUB 37.122}

While it has been shown that the structure of the preserved portion clearly indicates that the text was in fact a lexical list, a couple of observations are in order regarding some peculiarities of the list.

The first peculiarity is the presence of a repetition in the line 8' and 10' of column i. While repetitions of entries are not impossible in lexical lists, they usually occur when the corresponding entry in the parallel column(s) differ. Examples are not difficult to find, e.g. in the Ur $\mathrm{U}_{5}$-ra list tablet XVII lines 286-287 (also 288?) = Ras Shamra version 173-175, for two or three repetitions of ù.1uh "a small tree" with different Semitic correspondences ( $t i$ $i a-t u, n a-h u-r u-t u, h a-s ̌ a)$. Note, however, that in most cases repeated entries in the Sumerian column directly follow each other, which is not the case for KUB 37.122 i 8' and 10 '.

As for the criteria by which the entries are ordered, the only one seems to be the presence of a sequence of NUMUN signs; what follows in each line does not appear to be categorized according to either a graphic or a semantic rule.

The plants mentioned in these texts are edible or medical plants. All of them occur in medical and pharmaceutical texts of the Mesopotamian tradition (cf. also Commentary below), and some are also attested in the few medical texts from the Hattusa archives. ${ }^{7}$ Particularly interesting is the case of the sahlu-plant, that in Hattusa is attested with a peculiar sumerographic rendering $\mathrm{za}_{3} . \mathrm{ah} . \mathrm{li}$, e.g. in the Anitta text, where it seems to have a rather generic meaning of "grass/weed", but also in the collection of medical recipes KUB $37.1,{ }^{8}$ where it seems to have the typical meaning "cress", which is the one usually assumed for its occurrences in Mesopotamian tradition. Interestingly, this list does nor pattern with the other Hattusa occurrences in the graphemic rendering of the plant name, but rather with the standard writing that is employed in the Mesopotamian lists, $\mathrm{za}_{3} . \mathrm{hi}$.li. For an interpretation of this distribution and for further comments on the syllabary employed, cf. sections 4 and 6 below.

6 While a monolingual list may also be taken into consideration (e.g. a school exercise), possible Anatolian specimina such as the so-called Aufzählung von Soldaten KUB 37.123 (apparently exhibiting a mixed Babylonian ductus) provide for very weak comparanda, because of the miserable condition of the available text portions.

7 Some sequences of plants in the list are reminiscent of the series of plants attested in specific texts of the Mesopotamian medical tradition, in particular $\mathrm{u}_{2} . \breve{s}$ eš, $\mathrm{u}_{2}$.kur.ra and $\mathrm{za}_{3}$.hi.li.a.šar appear in the eye-disease text BAM 22: 4-5 (we thank Strahil Panayotov for making us aware of this occurrence); the ophtalmological texts found in Hattusa (CTH 809), however do not contain any relevant sequence.

8 Giusfredi 2012. 


\section{PALEOGRAPHY}

Although the tablet is very fragmentary and contains only a small number of signs, with a couple hardly legible, the occurrence of some diagnostic signs allows us to state that the ductus is definitely not Hittite.

Franz Köcher classified the script of KUB 37.122 as Middle Babylonian, ${ }^{9}$ together with those of several other tablets edited in the same volume. ${ }^{10}$ However, based on more recent studies, most of these tablets are now identified as Assyro-Mittanian (or, in one case, Middle Assyrian). ${ }^{11}$ Therefore, it is worth making a new palaeographic analysis also for KUB 37.122, in order to confirm or reject F. Köcher's statement.

As Elena Devecchi remarked, the major limitation of the palaeographic analysis of nonHittite tablets from Boğazköy is the lack of adequate working tools. ${ }^{12}$ For about 30 years, Hittitologists have relied on the Hethitisches Zeichenlexikon by Christel Rüster and Erich Neu (HZL), where a large collection of the different shape forms of the Hittite signs can be found. However, sign shapes occurring in Boğazköy tablets that do not show a Hittite ductus are either not recorded or, when they are, are not distinguished from the Hittite ones. Some specific works are available to us, such as Daniel Schwemer's analysis of the AssyroMittanian ductus ${ }^{13}$ or E. Devecchi's study on the so-called 'mixed ductus', ${ }^{14}$ but a complete palaeography of the Babylonian and Assyrian documents from Boğazköy is still lacking, and it is necessary to refer to the modern Mesopotamian sign lists or to specific studies, if available, since a personal investigation inside the mare magnum of Mesopotamian tablets is not such an easy challenge.

In what follows, we will remark on some of the signs found in KUB $37.122,{ }^{15}$ showing, as far as possible, differences and similarities with the Mesopotamian and Hittite ones. The comparison with the Hittite signs relies on the data collected by Ch. Rüster and E. Neu in the HZL, while those with Mittanian and Assyro-Mittanian ones are mostly based on D. Schwemer's sign list, with addenda by Mark Weeden ${ }^{16}$ and a personal check of the photographs of the other Assyro-Mittanian tablets listed in the Hethitologie Portal Mainz. ${ }^{17}$ For the ductus of the Mesopotamian tablets, we had to refer to Labat (1976) and Borger (ABZ, MZL); for the Middle Assyrian ductus, we also used the palaeographic table found in the edition of the letters from Tall Šēh Hamad provided by Eva Ch. Cancik-

Cf. KUB 37, iv.

KUB 37.2, 27, 44-49, 53, 54, 55, 61, 64, 69, 70, 82, 88, 100a, 105, 106.

11 On KUB 37.2, 55, 100a, and 106, see Weeden 2012, 230-231, with references. Furthermore, also KUB 37.27, 54, 61, 64, 69, 70, 88, and 105 are now classified as Assyro-Mittanian on the Hethitologie Portal Mainz, while KUB 37.44-49, belonging to the same tablet, are Middle Babylonian. KUB 37.82 is regarded as Middle Assyrian by Jeanette C. Fincke (2010, 48), although on the Hethitologie Portal Mainz there is no indication. Therefore, among the tablets classified by F. Köcher as Middle Babylonian, only KUB 37.122, at present, remains uncertain

See Devecchi 2012, 47-48.

Schwemer 1998.

Devecchi 2012.

All the images of the tablet are taken from the photo hethiter.net/: PhotArch BoFN04604a.

Weeden 2012. See also Weeden 2016.

Some of them, however, are classified as Mittanian by D. Schwemer (1998) and M. Weeden (2012). 
Kirschbaum. ${ }^{18}$ Conversely, we have been able to personally check the photographs of all the Boğazköy tablets that, according to the Hethitologie Portal Mainz, show a Middle Babylonian (24 tablets) and a Middle Assyrian (12 tablets) ductus, but we should note that, while Middle Babylonian tablets contain Sumerian and Akkadian magic rituals and incantations and may reflect the local copy of Mesopotamian texts, Middle Assyrian tablets are mostly letters sent from Assyria, ${ }^{19}$ thus not attesting a local syllabary.

The sign EDIN (fig. 1, a) has the shape usually found in Mesopotamian clay tablets, ${ }^{20}$ which also occurs in Assyro-Mittanian tablets (fig. 1, b-c) ${ }^{21}{ }^{21}$ whereas in the Hittite texts we find instead the "analytic" writing AM.SILA 3. BUR, ${ }^{22}$ typical of the Mesopotamian monumental writing (fig. 1, d).

Some remarks are in order about the damaged sign found in i 9' (fig. 2, a). As far as can be seen, it might be a variant of $\mathrm{DIM}_{3}$ (with an inscribed GAM) or, less probably, the more elaborate $\mathrm{DIM}_{8}$, also occurring in the Assyro-Mittanian tablet KUB 37.102(+) l.c. 4' (fig. 2, b). Other homophones of these signs cannot be excluded ${ }^{23}$ therefore, we opt for the transliteration $\operatorname{dim}_{x}$. As an alternative, although unlikely, it could be a Hittite LUGAL ( ${ }^{\mathrm{d}}$ lugal.me is a variant of the more common writing ${ }^{\mathrm{d}} \mathrm{dim}_{3}$. me), different from that occurring so far in Boğazköy tablets with a Middle Assyrian ductus, although all the occurrences are in letters, which do not reflect a local production (fig. $2, \mathrm{c}-\mathrm{d}$ ) ${ }^{24}$ and from that occurring in Mittanian texts, which consistently shows vertical wedges crossing the long horizontal below. In Assyro-Mittanian tablets, the sign LUGAL does not occur so far, but we could imagine that its shape was not different from the Middle Assyrian and Mittanian one, as it is derived from the sign $\mathrm{LU}_{2}$, which consistently shows the four verticals.

The sign LI, occurring in KUB 37.122 i 8' and 10' (fig. 3, a), has the shape usually found in Middle Assyrian, Neo-Babylonian, Assyro-Mittanian, and Mittanian, also characterising the New Hittite script (fig. 3, b). ${ }^{25}$ A similar shape has not been found so far in Middle Babylonian tablets from Boğazköy, where only the variant with one vertical wedge is attested (fig. 3, c). ${ }^{26}$ It also seems to be different from the LI usually found in Middle Assyrian tablets from Boğazköy, although to a lesser extent (fig. 3, d).

8 Cancik-Kirschbaum 1996, 73-87.

19 There are only two exceptions, KUB 37.198(+), which contains oil omens and is probably an imported tablet, not a local product (cf. Anor - Cohen 2018, 206), and KUB 47.41, a small fragment of the Libations to the Throne of Hepat.

20 See Labat 1976 no. 168 and Borger, MZL no. 300

21 See Schwemer 1998, 25.

22 HZL sub no. 168; cf. KBo 10.28+ v 1 and KBo 10.30+ ii 3', where EDIN.NA means 'hare', being either an haplographic writing or an abbreviation of one of the Sumerograms corresponding to Akkadian arnabu, all containing EDIN.NA (see Berman - Hoffner 1980, 49 with fn. 2). See also the lexical list KUB 3.94 ii 4, where EDIN.NA is written GA.SILÀ.BUR.NA and is translated by Akkadian șe-e-[ru] 'steppe'.

23 MZL no. 264.

24 See also Cancik-Kirschbaum 1996, 77.

25 Labat 1976 no. 59, Cancik-Kirschbaum 1996, 74, Schwemer 1998, 19, HZL no. 343.

26 KBo 36.19 1.c. 7'; KUB 30.1 i 4, 5; KUB 30.2 ii 9'; KUB 37.44+ i 15', 19', iv 8'. Despite the handcopy, LI has probably the same shape also in KBo 8.3, 6'. 
The peculiarity of the sign NUMUN (fig. 4, a), occurring at the beginning of every line in our tablet, is a large Winkelhaken above the horizontal wedge, starting before its head. Therefore, its shape is quite different from that usually found in Hittite texts, where the first Winkelhaken crosses the horizontal wedge (fig. $4, \mathrm{~d}$ ), ${ }^{27}$ and it rather resembles the NUMUN sometimes found in Middle Assyrian (seemingly not at Boğazköy, but the sign occurs only once and it is partly broken; cf. fig 4, c), Middle Babylonian, and Mittanian tablets (the first Winkelhaken usually starts after the head of the horizontal, but variants where it slightly precedes the horizontal are attested, as in the photo of the Middle Babylonian sign in fig. 4, b). ${ }^{28}$

The writing of numun $n_{2}$ is quite peculiar: it is usually written ZI\&ZI.LAGAB ${ }^{29}$ but in our tablet we find the writing ZI\&ZI.LAGAB\&LAGAB (fig. 5, a), a variant that, so far, is not recorded in any modern sign list. As far as we know, this variant seems only to occur at Emar $^{30}$ and in another tablet from Boğazköy, KUB 29.58+ iv 28 (fig. 5, b), ${ }^{31}$ a medical text containing Akkadian prescriptions against fever, whose ductus is so far undetermined (fig. $5) .{ }^{32}$ However, despite this peculiar writing of numun $\mathrm{n}_{2}$, a relationship between the scribal school that produced KUB 37.122 and the one that produced the medical text KUB 29.58 is unlikely, since, besides the different ductus, there are also spelling discrepancies between the two texts (see especially the typical Hittite variant $\mathrm{ZA}_{3}$.AH.LI for the sahlu-plant in KUB 29.58 v 13, while in KUB 37.122 we find the usual Mesopotamian spelling $\mathrm{za}_{3}$.hi.li.a).

The sign RA is also very peculiar (fig. 6, a): it is different from the common Hittite one (fig. 6, e), ${ }^{33}$ and its shape is more similar to that sometimes found in Middle Assyrian (fig. 6, b), Assyro-Mittanian (fig. 6, c), and Mittanian tablets. ${ }^{34}$ According to modern sign lists, the same shape also occurs in Middle Babylonian, but it is not found in any of the Middle

HZL no. 12.

Labat 1976 no. 72, Borger, MZL no. 117, Schwemer 1998, 20.

See Labat $1976 s u b$ no. 66, Borger, ABZ no. 66c, MZL no. 102.

Cf. Msk 7481h (= Emar 554 A; uncertain ductus), but not in Msk 74156a (= Emar 548 M, uncertain ductus)

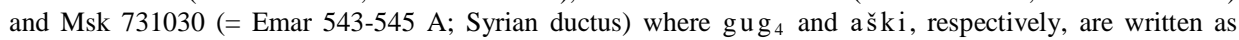
ZI\&ZI.LAGAB.

31 Edited by Meier 1939

32 The ductus of KUB 29.58 is quite puzzling and a brief look at the tablet reveals some remarkable peculiarities: the sign NA sometimes shows a small vertical wedge above the horizontal one, AH has usually the same shape of the "aleph"-sign (but there are also two occurrences of the Hittite variant), ANŠE and AZ show a subscribed PA, and the signs LI and TI have two different variants. The commixture of Hittite and non-Hittite signs in an Akkadian medical text, as well as the occurrence of the typical Hittite spelling $\mathrm{ZA}_{3}$.AH.LI for the sahlû-plant (with a Hittite $\mathrm{AH}$ ), may point either to a scribe with double training in Akkadian and Hittite, or to an attempt at writing an Akkadian text by a scribe usually employed for the drafting of Hittite documents (see the remarks by Devecchi 2012, 55-56 and Mora - Giorgieri 2004, 38 with regard to other texts).

33 See the variants in the HZL (no. 233): the last two are quite similar, although not identical, to that found in KUB 37.122, but unfortunately there is no indication about the tablets in which they are attested.

34 Labat 1976 no. 328, Borger, MZL no. 511, Cancik-Kirschbaum 1996, 81, Schwemer 1998, 30. 
Babylonian tablets from Boğazköy, which consistently show a RA closer to the Hittite one (fig. $6 \mathrm{~d})^{35}$

The shape of $\breve{S} E \check{S}$, typically Middle Babylonian and very similar to a Middle Assyrian variant (with less initial Winkelhaken, cf. fig. $7, \mathrm{~b}){ }^{36}$ which also occurs in texts from Boğazköy, is different from the variants recorded in the HZL (n. 79) for this sign, even the more complex ones, and the Hittite scribes usually preferred a simpler sign shape (fig. 7, c). The same variant also occurs in Mittanian letters, while in Assyro-Mittanian the sign is not attested so far.

The sign UM occurs twice in our tablet (i 11', 14') and has the shape found in Middle Assyrian and Assyro-Mittanian. ${ }^{37}$ Although variants with a similar shape also occur in Hittite, ${ }^{38}$ the common Hittite UM is usually simpler, strongly resembling the sign AB (HZL $\mathrm{n}^{\circ}$ 97, cf. fig. 8, c). Conversely, in our tablet, the two signs are kept distinct (fig. 8, a-b).

The sign $Z_{3}$ (fig. 9, a), occurring twice in our tablet (i 8', 10'), has the shape usually found in Hittite, Assyro-Mittanian, and Mittanian tablets, ${ }^{39}$ corresponding to one of the Old Babylonian and Middle Assyrian variants. ${ }^{40}$ The sign is rarely found in Middle Babylonian and Middle Assyrian texts from Boğazköy, where it shows a different shape (fig. 9, b-c), but the data cannot be regarded as conclusive.

Finally, the sign occurring in i 2' after the break (fig. 10, a) is probably a Middle Assyrian or Assyro-Mittanian variant of $\mathrm{ZU}$ (fig. 10, b), ${ }^{41}$ although it is not particularly diagnostic. We can also compare our sign to an Assyro-Mittanian SU (fig. 10, c), which differs from $\mathrm{ZU}$ in having one further wedge.

Summing up and trying to reach a provisional conclusion, we can be fairly sure that the script of KUB 37.122 does not correspond to the Middle-Babylonian ductus shown by Sumerian and Akkadian compositions found at Boğazköy (see particularly the signs RA and LI), nor to the Middle-Assyrian one characterising some letters and other documents imported into the Hittite capital (see e.g. LI, NUMUN, and $\mathrm{ZA}_{3}$ ). As emerges from the data collected, the script of our tablet mostly resembles the Assyro-Mittanian one, although evidence for some important diagnostic signs is lacking, because they do not occur so far in Assyro-Mittanian documents ( $\mathrm{NUMUN}_{2}$ and $\left.\breve{S} E \check{S}\right)$.

\footnotetext{
35 KBo 36.13 r.c. 4'; KBo 36.19 1.c. 8'; KBo 36.30, 7', 8'; KBo 40.104, 3'; KUB 30.1 i 3, iv 10'; KUB 30.2 ii 5'-8'; KUB 30.3, 3'; KUB 37.19, 4'; KUB 37.44 i 6', 20', 23', ii 4', 15', 16', iii 9; KUB 37.98, 5', 7'; KUB $37.110+, 5$ '.

36 Labat 1976 no. 331 and Cancik-Kirschbaum 1996, 81

37 Labat 1976 no. 134, Cancik-Kirschbaum 1996, 76, Schwemer 1998, 23.

Cf. e.g. KBo 9.82 obv. 2 and see the variants recorded in the HZL (no. 98).

HZL no. 238, Schwemer 1998, 30.

40 Labat 1976 no. 332

41 See also Weeden 2012, 247
} 


\section{TEXT AND COMMENTARY}

\subsection{Transcription}

col. i

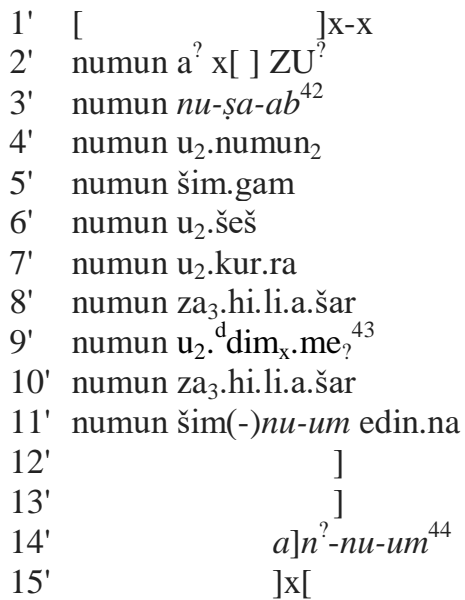

col. ii

$\begin{array}{ll}1^{\prime} & {[} \\ 2^{\prime} & {[\quad]} \\ 3^{\prime} & \text { n[umun } \\ 4^{\prime} & \text { num[un } \\ 5^{\prime} & \text { num[un } \\ 6^{\prime} & \text { numu[n } \\ 7 & \text { numun[ } \\ 8^{\prime} & \text { numun[ } \\ 9^{\prime} & \text { numun } x[ \\ 10^{\prime} & \text { numun } x[ \\ 11^{\prime} & \text { numun } x[ \\ 12^{\prime} & \text { numun } x[ \\ 13^{\prime} & \text { numun } x[ \\ 14 & \text { numun } \mathrm{u}_{2}[ \\ 15^{\prime} & \text { numu]n[ }\end{array}$

42 The sign $\mathrm{ZA}$ is not readable on the photos from the Vorderasiatisches Museum in Berlin, available on the Hethitologie Portal Mainz (http://www.hethiter.net) The unreadable sign seems to be shorter than $1 \mathrm{~cm}$, which makes the ZA drawn by F. Köcher very likely. On the interpretation of $n u-s ̦ a-a b$ and its occurrences in lexical lists and medical texts, see below, Commentary.

43 The sign is poorly readable as the expected $\mathrm{DIM}_{3}$. A variant of it appears, however, to be the only possible candidate. The attested variant of this writing with LUGAL instead of DIM 3 is unlikely given the shape of the sign. For discussion, see above, Paleography; for the interpretation, see below, Commentary.

44 The sign before NU might be AN, but it is only partly recognizable. 


\subsection{Commentary}

3': nușabu corresponds to ${ }^{\text {u2 }} \mathrm{a}-\mathrm{a}-\mathrm{ar}-\mathrm{ku}_{3}-\mathrm{babbar}$ in MSL XVII, 188 (= An-ta-gal ${ }_{2}$ Tablet A, line 198). The alternative Semitic correspondence ajar kašpi is also attested in several medical texts. ${ }^{45}$ In this case, we may be dealing a pseudo-sumerographic writing (NU.ZA.AB). One should, in any case, compare the Aramaic $n s ̦ b$ ("to plant"), which makes it reasonable to assume that nuṣabu was the West-Semitic form, and ajar kašpi the Akkadian one. It is significant that the variant used in this document is the former, not the latter.

4': šikkurratu-plant: According to Wolfram von Soden ${ }^{46}$ this plant may have been "ein Teil des Schilfrohres(?)". Is the writing $\mathrm{u}_{2}$.numun ${ }_{2}$ different from $\mathrm{u}_{2} \cdot \mathrm{a} \cdot \mathrm{numun} \mathrm{n}_{2}$ (Akkadian elpetu mê in $\mathrm{Ur}_{5}$-ra Tablet XVII, lines $9^{47}$ )? Other possible readings of the sequence, however, may be $\mathrm{u}_{2} . \mathrm{aški}$ or $\mathrm{u}_{2} \cdot \mathrm{gug}_{4}$, which would correspond to Akkadian kuštu, urbatu (Diri Tablet IV $11 \mathrm{ff}$.), šišnu (Uru-an-na I 92), umșatu and šubbatu (Ur $\mathrm{Ur}_{5}$-ra Tablet XVII, lines 6ff.). ${ }^{48}$

5': following MSL V, 102 (= Ur 5 -ra Tablet III, line 113), Sumerian šim.gam could correspond to Akkadian șumlalû.

6': In MSL X, 83 (Ur 5 -ra Tablet XVII, line 37) Akkadian lardu (also laradu) corresponds to $\mathrm{u}_{2}$-šeš-gal, but in other lexical lists Akkadian lardu corresponds to other Sumerian entries: $\mathrm{u}_{2} . \mathrm{ki} . \mathrm{kal}, \mathrm{u}_{2}$-hi-ri-in, $\mathrm{u}_{2}$.kun.gal ( $\mathrm{Ur}_{5}-\mathrm{ra}$ Tablet XVII, lines 34-36; also MSL XV, $150=$ Diri Tablet IV line 21).

7': Sumerian $\mathrm{u}_{2} \cdot \mathrm{kur}$.ra corresponds to 3 different Akkadian words in the lexical lists: maltakal in MSL X, 88 ( $=\mathrm{Ur}_{5}$-ra Tablet XVII, 131; in the texts from Hattusa also KUB 37.43 i 9: $\mathrm{u}_{2}$.kur.ra; ib. i 8: $\mathrm{u}_{2}$.kur.kur.ra $\left.{ }^{49}\right)$; ninü $^{50}$ and azupiru ${ }^{51}$ in MSL X, 114 (= $\mathrm{Ur}_{5}$-ra Ras Shamra, 188).

8': Akkadian sahlû, edible and medical plant. Cf. numun za 3 .hi.li. šar MSL X, 95 (= Ur $_{5}$-ra Tablet XVII, 326); also in Old Babylonian Nippur Ura 4 Seg.5, 5: numun hi.li.a sar-ra. The writing $\mathrm{za}_{3}$.ah.li is also attested in Hattusa, e.g. in the medical text KUB 37.1, passim ${ }^{52}$ also in different context in Anitta text CTH 1.A = KBo 3.22 rev. 48 with Hittite phonetic complementation $\mathrm{ZA}_{3}$.AH.LI-an. ${ }^{53}$ Furthermore, in the Akkadian medical text KUB 29.58 v 13, which is palaeographically puzzling, the "Hittite" writing $Z_{3}$.AH.LI is found, and the sign AH shows the typical Hittite shape, occurring only one other time in this tablet (iii 30), while the scribe uses in other contexts the "aleph"-sign with the value

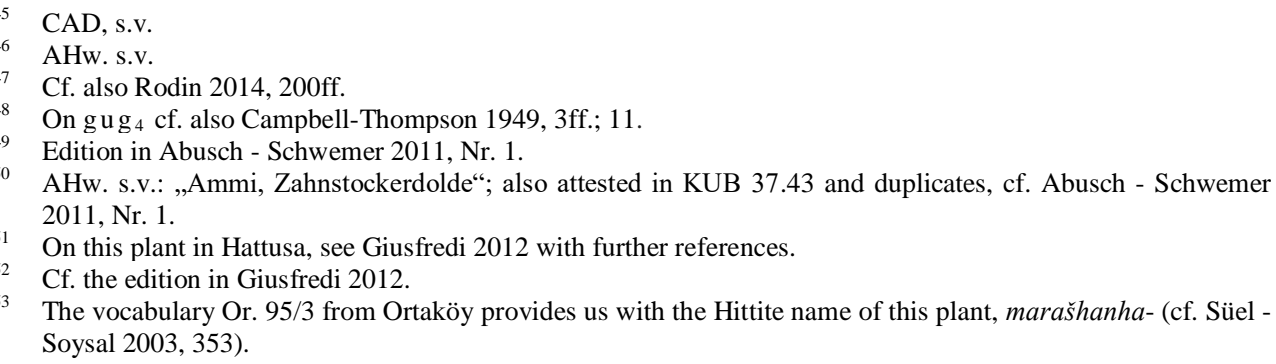


$V h .{ }^{54}$ Here in KUB 37.122, the occurrence of the standard Mesopotamian writing, which in

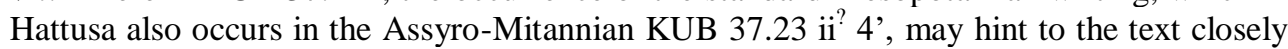
depending on the re-elaboration of Sumerian and Akkadian lexical materials.

9': ${ }^{\mathrm{d}} \mathrm{dim}_{\mathrm{x}} . \mathrm{me}$ is graphic variant of $\mathrm{u}_{2} \cdot{ }^{\mathrm{d}} \mathrm{dim}_{3} . \mathrm{me}$, which, in turn, is the Sumerian writing corresponding to Akkadian Lamaštu. ${ }^{55}$ Thus, the sequence $\mathrm{u}_{2} \cdot{ }^{\mathrm{d}} \mathrm{dim}_{3} . \mathrm{me}_{\text {? }}$ is apparently written for the šamme lamašti also attested in the list MSL X, 89, 103 (= $\mathrm{Ur}_{5}-\mathrm{ra}$ Tablet XVII line 1, Ur 5 -ra Tablet XVII rec. B, line 182) and in Boğazköy in KBo 21.20 obv. 16'. This unidentified plant is also attested in the Mesopotamian medical texts (e.g. BAM 4,379 ii 8f., BAM 5, 423 i 18 and 438 r. 10). ${ }^{56}$

10': see above, line 8 '.

11': very unclear line, with an obvious Akkadian ending -nu-um, which may be compared to several plant names.

14': the signs -nu-um are relatively well readable at the end of line 14'; they could, however, be the Akkadian termination of a number of Akkadian plant names. As double entries exist in this column of the list, it cannot be excluded that the line is a repetition of the šim(-)nu-um in line 11', without the Sumerian genitive edin.na at the end.

\section{SOME CONCLUSIVE REMARKS}

While its contents have been quite clearly described in the previous pages, the text KUB 37.122 triggers some reflections on both the composition of lexical lists in Hattusa and the role(s) played by the Akkadian language in the Hittite capital city.

As is well known, although sometimes forgotten, the Akkadian language employed in the Hittite kingdom was anything but a unitary and homogeneous reality. This means that, within the Akkadian texts found in the Hittite tablet collections, different types of Akkadian can be identified, which differ according to the origin of the texts - that is, whether they were a local production or imported materials - the genre to which they belong, the functions they had, as well as the origin and the training of the scribes in charge of drafting them. We will not try to cover the problem of the Akkadian language in the Hittite world entirely, but we wish to add a contribution to the topic by commenting on the position of KUB 37.122 in the context of the Hattusa textual and lexical production.

The Akkadian writing world was, beyond any reasonable doubt, the cultural source of the introduction of Cuneiform writing in the Hittite Anatolia. Regardless of the position one wishes to take on the date of the first Hittite texts written by the Hittites - and excluding texts that were certainly composed by or following the habits of non-Anatolian scribes as the Tikunani letter and the Uršu text ${ }^{57}$ - the Akkadian employed in the texts that were traditionally labelled as paleographically Old Hittite ${ }^{58}$ represents a variety that should, reasonably, have played a role in the definition of the inventory of Akkadograms that will

\footnotetext{
54 The same writing $\mathrm{ZA}_{3}$.AH.LI is also employed in the Hittite ritual with Akkadian sections CTH 432, edited by Gary M. Beckman (2007). According to the CAD S, 62, the writing ZA 3 .AH.LI.A allegedly occurs in the Old Babylonian letter CT 52, 5: 11; however, based on the handcopy of the tablet, the second sign is probably HI.

55 Campbell-Thompson 1949, $24 \mathrm{ff}$.

56 See also Wiggermann 2000, 238.

57 van den Hout 2009 and Archi 2010.

$58 \mathrm{OH}$ in the CHD system, aheth. in the $\mathrm{HW}^{2}$.
} 
be employed for the later texts. Akkadian was famously also employed as a lingua franca for Ancient Near Eastern diplomacy. It is however evident that more technical Akkadian traditions existed as well. This is testified by literary texts, oracles, wisdom texts, ritual compositions, and also by medical texts, all of which go back directly or indirectly to the Mesopotamian literature. The language of specific rituals has undergone investigations, e.g. the CTH 718, edited by G.M. Beckman, ${ }^{59}$ or the KBo 36.29 with related fragments, edited by D. Schwemer. ${ }^{60}$ in these two cases, the shape of the signs employed generally differ, with $\mathrm{CTH} 718$ being $\mathrm{NH}$ and KBo 36.29 being Assyro-Mittanian, but the language is, in both cases, the result of a commixture of Assyrian, Babylonian and "West peripheral Akkadian" elements.

When dealing with an atypical lexical list such as KUB 37.122, it is reasonable to wonder to what extent it derived from the lexical materials from the Mesopotamian world, and, as a consequence, whether it was related to the presence of Mesopotamian scribes in the Hittite capital city. There is clear evidence that Mesopotamian scholars - scribes, physicians, and other experts - with different schooling backgrounds lived permanently at Hattusa with their families, also being employed in the royal administration, ${ }^{61}$ and this can easily account for both the presence of foreign materials in the Hittite capital and their lack of homogeneity in language and writing. Indeed, coming to Hattusa, these scribes probably brought some tablets with them, and, once established in the Hittite capital, they certainly produced new tablets, in close contact with other scribes, either Hittite scribes or those coming from different places.

In this complex scenario, the evaluation of a fragmentary document such as KUB 37.122 can be a very difficult task. As outlined above, the ductus of the text is close to the Boğazköy Assyro-Mittanian one. We should note that all the documents showing this kind of ductus are magic or medical texts, ${ }^{62}$ while no lexical list, at least so far, seems to display an Assyro-Mittanian ductus. This may represent a counter-argument to the hypothesis that our fragment is a lexical list, unless we imagine that this document could have served some useful purpose either for a ritual practitioner or for a scribe in charge of drafting medical texts. Indeed, since, as far as we know, there are no Mesopotamian parallels for the text contained in this small fragment, we may provisionally suggest that KUB 37.122 could represent a local lexical list produced for such a specific practical purpose. Unfortunately, the lack of the second column is a major obstacle to a full understanding of the text, and does not allow us to determine, for instance, if the scribe was a Mesopotamian, as the writing $\mathrm{za}_{3}$.hi.li.a for the sahlû-plant may suggest, or belonged to a different Cuneiform tradition, and therefore wanted to record that the $\mathrm{za}_{3}$.hi.li.a-plant, unusual to him but sometimes occurring in the texts that he used to deal with, corresponded to the more familiar $\mathrm{za}_{3}$.ah.li / sahlû / marašhanha-.

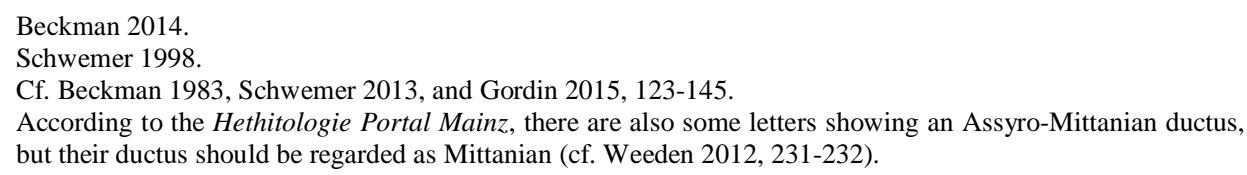




\section{REFERENCES}

ABUSCH, I.T. - SCHWEMER, D.

2011 Corpus of Mesopotamian anti-witchcraft rituals, Volume 1, Leiden 2011.

ANOR, N. - COHEN, Y.

2018 The Oil Omens from Hattuša: An Investigation of the History and Transmission of a Babylonian Divination Compendium: Journal of Near Eastern Studies 77 (2018), pp. 195206.

ARCHI, A.

2010 When Did the Hittites Begin to Write in Hittite?: Y. COHEN - A. GILAN - J.L. MiLLER (eds.), Pax Hethitica. Studies on the Hittites and their Neighbours in Honour of Itamar Singer (Studien zu den Boğazköy-Texten 51), Wiesbaden 2010, pp. 37-46.

BECKMAN, G.M.

1983 Mesopotamians and Mesopotamian Learning at Hattuša: Journal of Cuneiform Studies 35 (1983), pp. 97-114.

2007 A Hittite Ritual for Depression (CTH 432): D. GRODDEK - M. ZoRMAN (eds.), Tabularia Hethaeorum. Hethitologische Beiträge Silvin Košak zum 65. Geburtstag (Dresdner Beiträge zur Hethitologie 25), Wiesbaden 2007, pp. 69-81.

2014 The babilili-Ritual from Hattusa (CTH 718) (Mesopotamian Civilizations 19), Winona Lake 2014.

BERMAN, H. - HOFFNER, H.A. JR.

1980 Why parhu- is not is not the Hittite word for "fish": Journal of Cuneiform Studies 32 (1980), pp. 48-49.

CAMPBELL-THOMPSON, R.

1949 A Dictionary of Assyrian Botany, London 1949.

CANCIK-KIRSCHBAUM, E.Ch.

1996 Die mittelassyrischen Briefe aus Tall Šẹh Hamad (Berichte der Ausgrabung Tall Šēh Hamad/Dūr katlimmu 4.1), Berlin 1996.

DEVECCHI, E.

2012 The So-called Mixed Ductus in the Akkadian Texts from Boğazköy: E. Devecchi (ed.), Palaeography and Scribal Practices in Syro-Palestine and Anatolia in the Late Bronze Age. Proceedings of the International Symposium held in Leiden December 17-18, 2009 (PIHANS 119), Leiden 2012, pp. 47-63.

FINCKE, J.C

2010 KUB 37, 201: Ein weiteres ŠÀ.ZI.GA-Fragment aus Hattuša: Nouvelles Assyriologiques Brèves et Utilitaires 2010/2, pp. 48-49.

GIUSFREDI, F.

2012 KUB 37, 1: an Akkadian Medical Text from Boğazköy: Altorientalische Forschungen 39 (2012), pp. 49-63.

Gordin, SH.

2015 Hittite Scribal Circles. Scholarly Tradition and Writing Habits (Studien zu den BoğazköyTexten 59), Wiesbaden 2015.

LABAT, R.

1976 Manuel d'Épigraphie Akkadienne: Signes, Syllabaire, Idéogrammes, Paris 1976.

MEIER, G.

1939 Ein akkadisches Heilungsritual aus Boğazköy: Zeitschrift für Assyriologie und Vorderasiatische Archäologie 45 (1939), pp. 195-215. 
MORA, C. - GIORGIERI, M.

2004 Le lettere tra $i$ re ittiti e $i$ re assiri ritrovate a Hattuša (History of the Ancient Near East. Monographs 7), Padova 2004.

RODIN. TH.

2014 The World of the Sumerian Mother Goddess. An Interpretation of Her Myths (Acta Universitatis Upsaliensis. Historia Religionum 35), Uppsala 2014.

SCHEUCHER, T.S.

2012 The Transmissional and Functional Context of the Lexical Lists from Hattuša and from the Contemporaneous Traditions in Late-Bronze-Age Syria, Ph.D. Dissertation, Leiden 2012.

SCHWEMER, D.

1998 Akkadische Rituale aus Hattuša. Die Sammeltafel KBo XXXVI 29 und verwandte Fragmente (Texte der Hethiter 23), Heidelberg 1998.

2013 Gauging the influence of Babylonian magic: The reception of Mesopotamian traditions in Hittite ritual practice: E.CH. CANCIK-KIRSChBAum - J.W. Klinger - G.G.W. MüLleR (eds.), Vielfalt und Normierung / Diversity and Standardization. Perspektiven altorientalischer Kulturgeschichte, Berlin 2013, pp. 145-171.

SÜEL, A. - SOYSAL, O.

2003 A Practical Vocabulary from Ortaköy: G. BECKMAN - R. BEAL - G. MCMAHON (eds.), Hittite Studies in Honor of Harry A. Hoffner Jr. on the Occasion of His 65th Birthday, Winona Lake 2003, pp. 349-365.

VAN DEN HOUT, TH.P.J.

2009 Reflections on the Origins and Development of the Hittite Tablet Collections in Hattuša and Their Consequences for the Rise of Hittite Literacy: F. PECCHIOLI DADDI - G. TORRI - C. CORTI (eds.), Central-North Anatolia in the Hittite Period. New Perspectives in Light of Recent Research. Acts of the International Conference Held at the University of Florence (7-9 February 2007) (Studia Asiana 5), Rome 2009, pp. 71-96.

WEEDEN, $\mathrm{M}$

2012 Assyro-Mittanian or Middle Assyrian?: E. DeVeCCHI (ed.), Palaeography and Scribal Practices in Syro-Palestine and Anatolia in the Late Bronze Age (PIHANS 119), Leiden 2012, pp. 229-251.

2016 Hittite Scribal Culture and Syria. Palaeography and Cuneiform Transmission: Sh. YAMADA - D. ShibAtA (eds.), Cultures and Societies in the Middle Euphrates and Habur Areas in the Second Millennium BC. I. Scribal Education and Scribal Traditions (Studia Chaburensia 5), Wiesbaden 2016, pp. 157-191.

WigGERMANN, F.A.M.

2000 Lamaštu, daughter of Anu. A profile: M. Stol (ed.), Birth in Babylonia and the Bible. Its Mediterranean Setting (Cuneiform Monographs 14), Groningen 2000, pp. 217-252. 


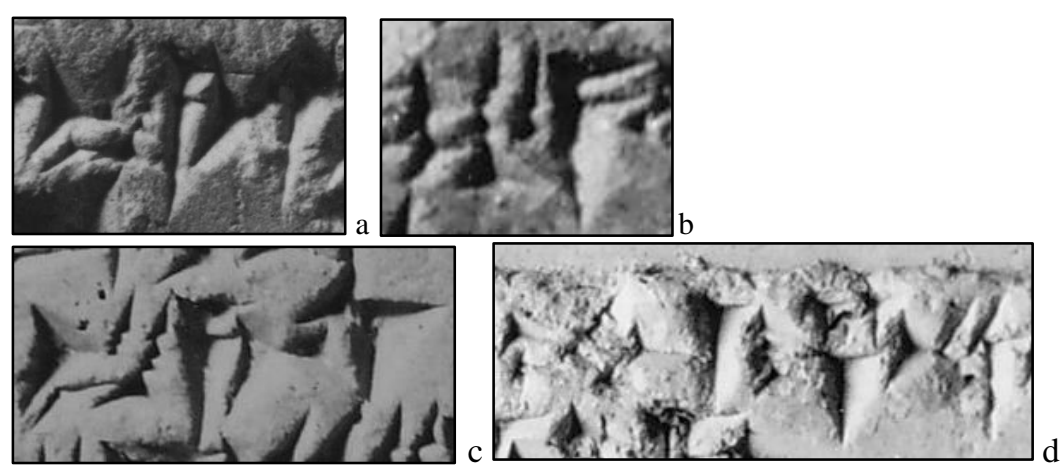

Fig. 1 - EDIN.NA: a, KUB 37.122 i 11'; b, KUB 37.198+ rev. 4 (EDIN, Middle Assyrian ductus, photo: hethiter.net/: PhotArch BoFN02807); c, KUB 37.9 i 5' (Assyro-Mittanian ductus, photo: hethiter.net/: PhotArch BoFN04147a); d, KBo $10.28+$ v 1 (= AM.SILA 3 .BUR.NA, Hittite ductus, photo: hethiter.net/: PhotArch Phb00307c).
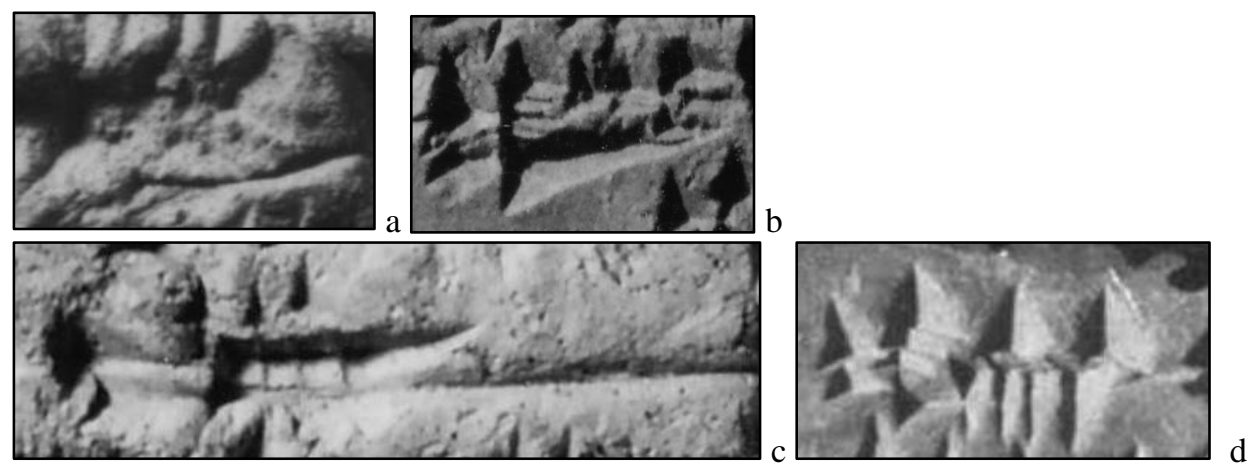

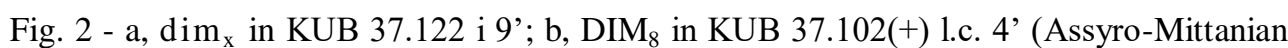
ductus, photo: hethiter.net/: PhotArch Phb09660); c-d, LUGAL in KBo 28.59 obv. 1 and KBo 1.20 obv. 12' (both Middle Assyrian ductus, photos: hethiter.net/: PhotArch b6818 and hethiter.net/: PhotArch BoFN01271).
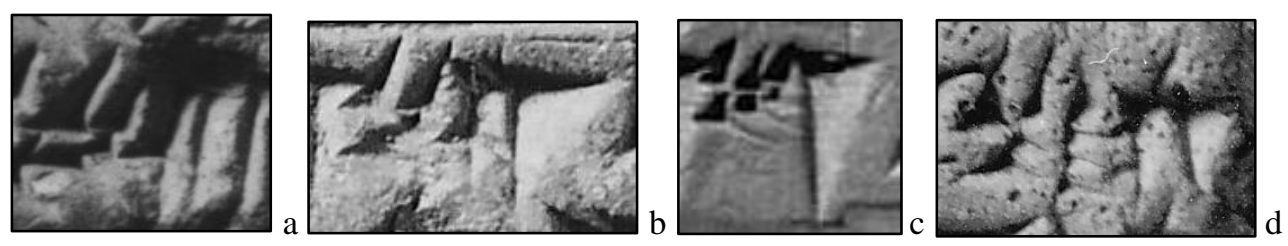

Fig. 3 - LI: a, KUB 37.122 i 8'; b, KUB 37.10, 8' (Assyro-Mittanian ductus, photo: hethiter.net/: PhotArch BoFN04483b); c, KUB 30.1 i 5 (Middle Babylonian ductus, photo: hethiter.net/: PhotArch N12751); d, KBo 28.61 obv. 17' (Middle Assyrian ductus, photo: hethiter.net/: PhotArch BoFN04184). 

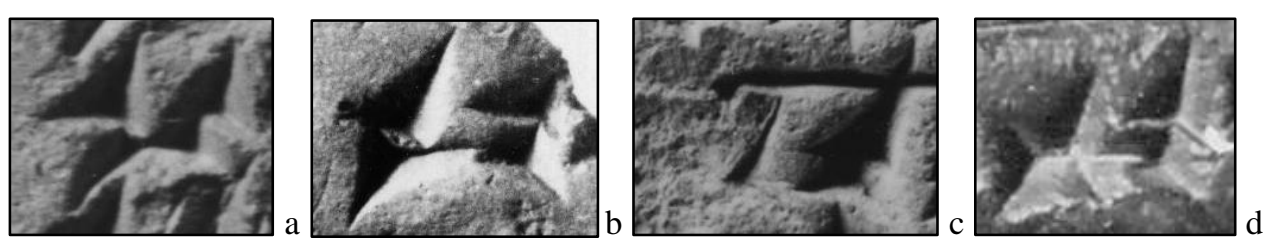

Fig. 4 - NUMUN: a, KUB 37.122 i 7’; b, KUB 37.98, 4' (value kul, Middle Babylonian ductus, photo: hethiter.net/: PhotArch BoFN12918a); c, KBo 28.62+ obv. 12' (Middle Assyrian ductus, photo: hethiter.net/: PhotArch BoFN07155); d, KUB 26.12+ i 11' (Hittite ductus, photo: hethiter.net/: PhotArch BoFN01437).
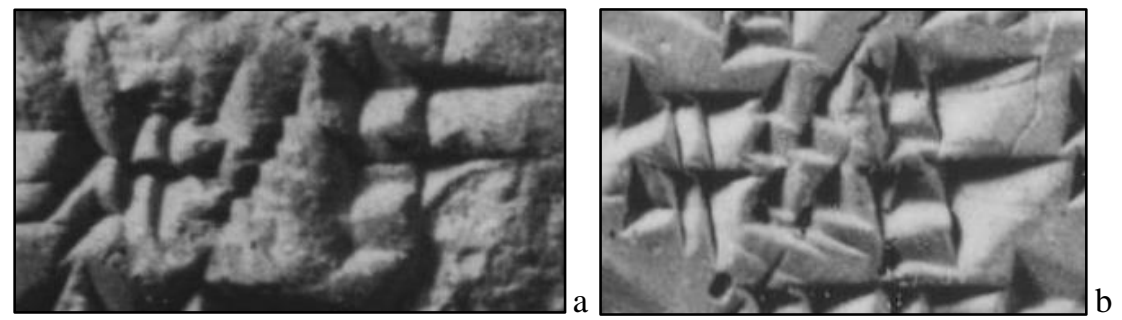

Fig. 5 - numun 2 (ZI\&ZI.LAGAB\&LAGAB): a, KUB 37.122 i 4'; b, KUB 29.58+ iv 28 (unclear ductus, photo: hethiter.net/: PhotArch BoFN06372).
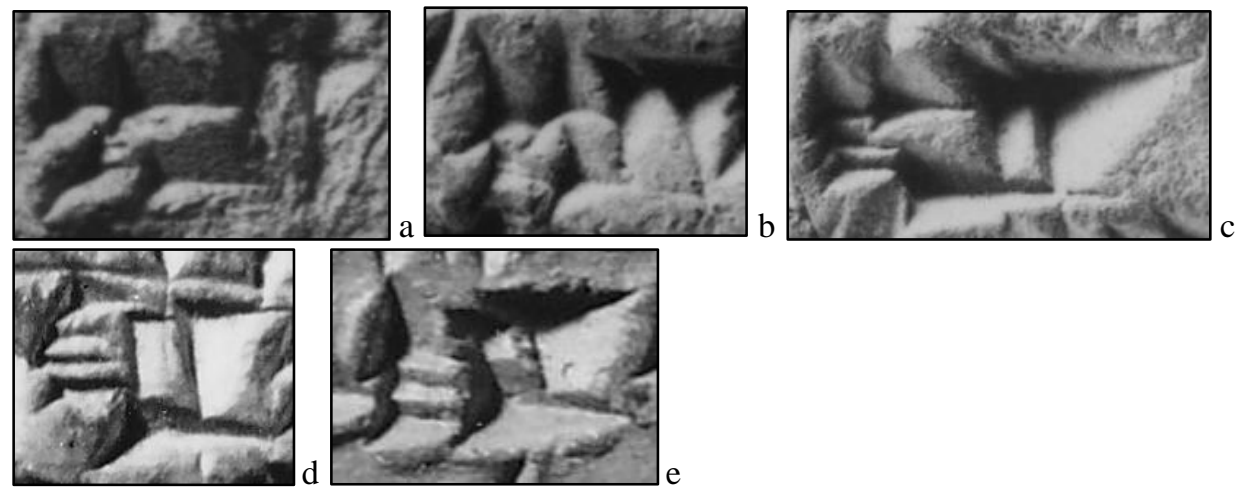

Fig. 6 - RA: a, KUB 37.122 i 7'; b, KBo 28.62(+) obv. 12' (Middle Assyrian ductus, photo: hethiter.net/: PhotArch BoFN07155); c, KUB 37.43 i 8' (Assyro-Mittanian ductus, photo: hethiter.net/: PhotArch BoFN07222); d, KUB 37.47+ ii 4' (Middle Babylonian ductus, photo: hethiter.net/: PhotArch BoFN04543c); e, KBo 27.149, 9' (Hittite ductus, photo: hethiter.net/: PhotArch BoFN04478a). 

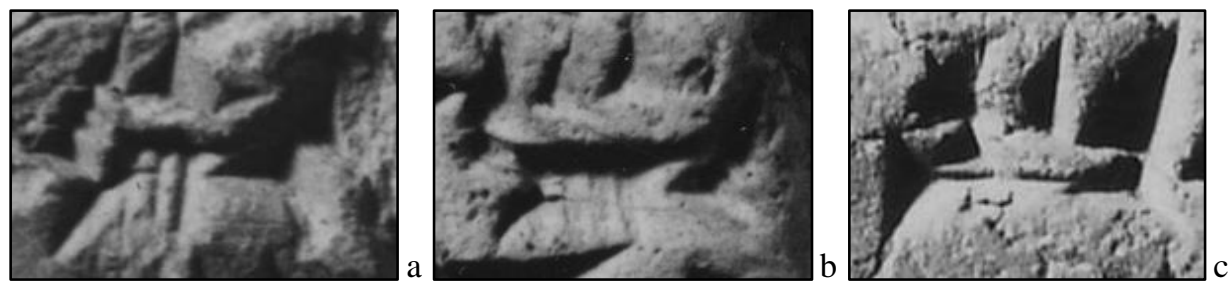

Fig. 7 - ŠEŠ: a, KUB 37.122 i 6'; b, KBo 28.73, 6' (Middle Assyrian ductus, photo: hethiter.net/: PhotArch BoFN07779b); c, KUB 23.102 i 5' (Hittite ductus, photo: hethiter.net/: PhotArch BoFN01188).
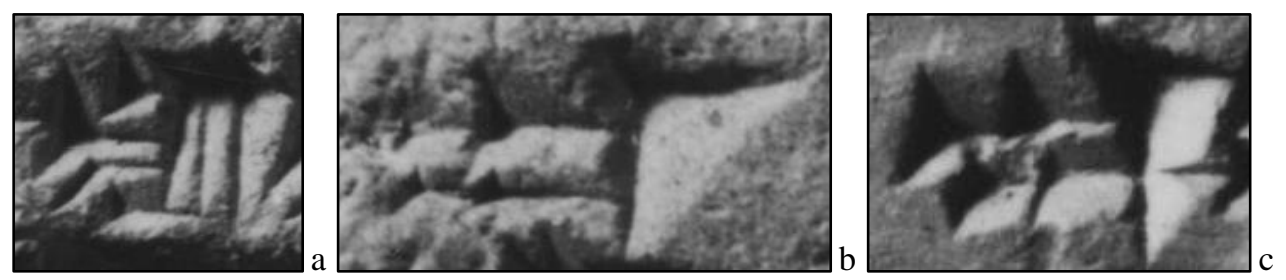

Fig. 8 - a, UM in KUB 37.122 i 11'; b, AB in KUB 37.122 i 3'; c, UM in KUB 36.37+ iii 14' (Hittite ductus, photo: hethiter.net/: PhotArch BoFN09654).
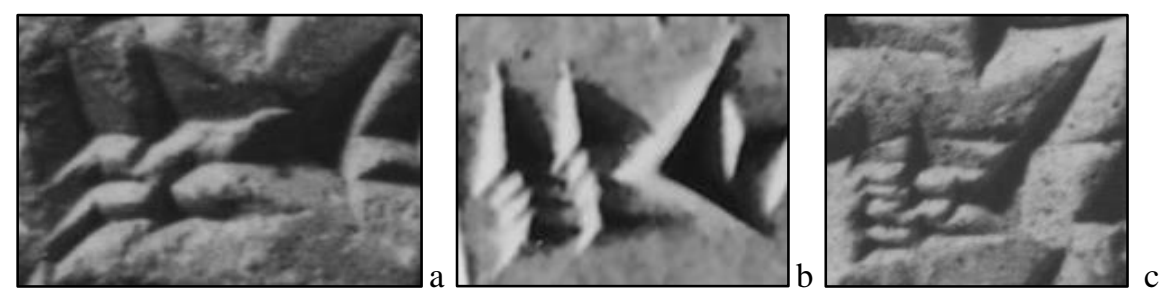

Fig. 9 - ZA 3 : a, KUB 37.122 i 8'; b, KBo 36.33, 3' (Middle Babylonian ductus, photo: hethiter.net/: PhotArch Phb03244a); c, KUB 34.5(+) rev. 4' (= 25) (Middle Assyrian ductus, photo: hethiter.net/: PhotArch BoFN02706b).
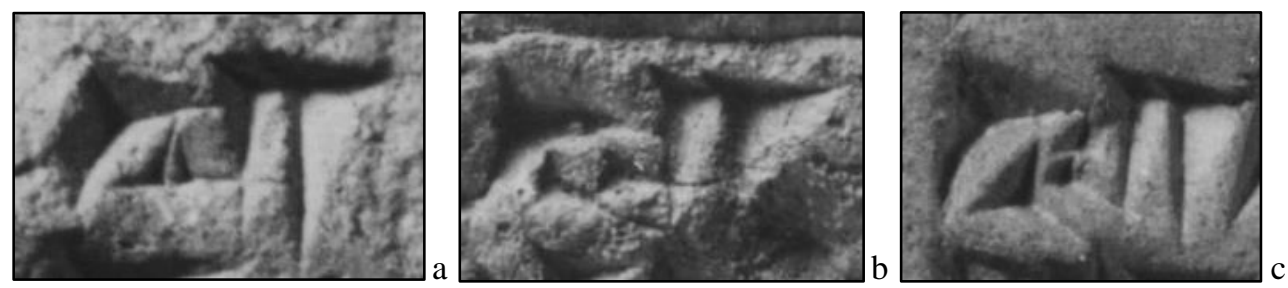

Fig. 10 - a, ZU' in KUB 37.122 i 2'; b, ZU in KUB 37.115+ rev. 15' (Assyro-Mittanian ductus, photo: hethiter.net/: PhotArch BoFN05415); c, SU in KUB 37.107, r.c. 10' (Assyro-Mittanian ductus, photo: hethiter.net/: PhotArch BoFN04826b). 